\title{
The Impediments and Evolution of Derivatives in Sub Sahara Africa
}

\author{
WILBERT KUDAKWASHE CHIDAUSHE
}

Department of Accounting and Finance, Botho University, Gaborone, Botswana.

\begin{abstract}
The research follows on the Arusha declaration of 2005 and the global financial crisis of 2008 and explored the impediments and the evolution of derivatives in Sub Sahara Africa with special attention on Zimbabwe, Botswana and South Africa. The research has been based on a review of literature of the seminal authors and through a conduct of questionnaire surveys in each of the three countries of Zimbabwe, Botswana and South Africa. The purpose of the study was to identify any disparities in the evolution of commodities and financial derivatives in the Sub-Saharan African countries. The study uncovered that registered banks in Botswana and Zimbabwe relied so much on the forward agreement to protect against financial risk. Credit default swaps (CDS), currency options and simple foreign exchange swaps also were relatively used in Botswana by most commercial banks to hedge against risk. In South Africa, a wide variety of simple and complex futures and options products are effectively applied on commodities and currencies to protect against financial losses. Rodrigues, Schwarz and Seeger (2012) noted that the initiation of formal derivative markets can accelerate growth in the economies and decrease the fluctuations of the Gross Domestic Product.
\end{abstract}

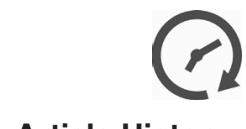

\section{Article History}

Received: 27 July 2018

Accepted: 25 September 2018

\section{Keywords}

Commodity Derivatives;

Evolution;

Impediments.

\section{Introduction}

A derivative was defined as a financial instrument with a value that is derived from the price of other basic underlying variables or traded assets. Further it was reiterated that the derivatives can be reliant on almost any variable for instance from the prices of hogs and to the amount of snow falling at a specific place of resort. Derivative products are used to hedge against weather risk and price risk arising from the fluctuation of prices of currencies, commodities, energy products and metals. The main categories of derivatives that are applied globally

CONTACT Wilbert Kudakwashe Chidaushe 1 wilbert.chidaushe @ bothouniversity.ac.bw 9 Department of Accounting and Finance, Botho University, Gaborone, Botswana.

\section{(c) (i)}

(C) 2018 The Author(s). Published by Enviro Research Publishers.

This is an Open Access article licensed under a Creative Commons license: Attribution 4.0 International (CC-BY).

Doi: http://dx.doi.org/10.12944/JBSFM.01.01.04 
are; forward agreements, options, swaps and futures. Derivative products are useful for price discovery of currencies, commodities, metals, energy products, metals and a variety of other products including in real estate. ${ }^{1}$

A forward contract is an agreement between counterparties to deliver a specified currency, commodity or metal or any other product at a specific date at a price agreed well in advance. ${ }^{2}$ The only different between a forward and futures contracts is that futures are standardized and are traded in regulated exchanges whilst the trading of a forward contracts does not necessary require a physical market place but are rather traded over the counter (OTC), for instance OTC deals can be conducted over a communication network or telephone line. Futures contracts are standardized forward agreements to deliver specific quantity of currency, commodities or metals or energy products at a specific price and at a specific date in the future. Options is the right and not the obligation to buy or sell specified quantity of currencies, commodities or energy products and metals at a pre-determined price known as the strike price. Swaps contracts are agreements between counterparties to exchange a series of cash flows at specified rate at specified dates in the future.

The following conditions are necessary for the development of derivatives; a robust clearing and settlement system, appropriate timing of the market development, appropriate economic conditions, financial integrity, international integration, qualified personnel, an appropriate legal and regulatory framework that permit derivative trading and that enable contract enforcement and protection of rights. ${ }^{3}$

Derivatives products particularly swaps has been labeled as financial weapons of mass destruction and were blamed for triggering the 2007/2008 financial crisis. ${ }^{4}$ Following the financial crisis regulatory reforms such as those of the Dodd Frank Act of 2010 has been enacted particularly addressing problems of Over the Counter swaps derivatives. Many derivatives reforms have followed suite all over the world through the adoption of the Dodd Frank act by G-20 member countries through pronouncements of the International Organization for Securities Exchange (IOSCO) and the Bank of International Settlements (BIS).

\section{The History of Evolution of Derivatives in Africa The Arusha Declaration and Plans of Action on African Commodities Derivatives}

In Tanzania, in the city of Arusha, a conference on the importance of addressing the volatility of commodity prices in Africa was held by the African Union for ministers of trade and commodities. The conference was held from the $21^{\text {st }}$ of November to $23^{\text {rd }}$ November 2005 to further discuss on the mandate that was given to the African Union Commission to develop derivative schemes to solve commodity problems in African countries. At the Arusha conference it was recognized that commodity derivatives would result in an equitable price discovery for commodities in Africa and would play an important role in addressing poverty and in the improvement of the standard of living in the rural population of Africa. ${ }^{5}$

\section{Declaration at Arusha Conference}

It was declared at the conference that one of the challenges faced by the international community in the commodity sector was volatility of commodity prices. In addition it was noted that the objective of the conference was to explore mechanisms to achieve fair and stable prices for producers of African commodities. It was recommended that suitable models for the management of commodity risks at the farm and national level should be developed to decrease the vulnerability of farmers to price volatility and loss of income. It was propounded that necessary measures to diversify geographically towards innovative higher value products shall be taken to add value in the African economies and the promotion of public to private partnerships as important vehicles towards the development of derivatives products was emphasized.

\section{The Arusha Plan of Action on Africa Commodities Exchange}

The plan of action at Arusha was a commitment by the ministers to the initiation and establishment of commodity derivatives exchanges and to encourage African Union to allow private sector parties to discuss such initiatives, impediments and requirements of establishing commodity derivatives markets in African countries. Another plan of action 
was to identify specific supportive actions on the establishment of commodity derivatives through which the public interest would be protected. A further plan of action was to sponsor research and writing of technical papers on the practicalities of commodity derivative exchange development in the African context and including a set of best practices and guidelines on the best use of commodity derivative transactions to hedge commodity price risk in Africa.

\section{The History of Development of Derivative Market in Zimbabwe}

The Zimbabwe Agricultural Commodity Exchange (ZiMACE) was established in 1994 and was closed in 2001 after the government took control of grain and wheat trading through the establishment of the Grain marketing Board (GMB). In 2010 the government of Zimbabwe announced the initiation of the Commodity Exchange of Zimbabwe (COMEX) and up to now it has not started operations. The Zimbabwe Agricultural Commodity Exchange was founded following an initiative by the private sector.

\section{The History of Development of Derivatives Markets in Botswana}

According to Bloomberg, Bourse Africa "was formerly known as Global Board of Trade Limited and changed its name to Bourse Africa Limited in October 2013. The company was founded in 2007 and is based in Ebene Cyber City, Mauritius." (see https://www.bloomberg.com/research/stocks/private/ snapshot.asp? privcapid=51454534).

Bourse Africa was set to commence derivative trading in March 2010, but rather skipped Botswana and set up a derivative exchange in Mauritius in October 2010. In addition in Botswana on 30 July 2012, at a ceremony where Bourse Africa was preparing to unveil the Pan Africa commodity exchange to initiate a derivative project by the end of 2012, the then assistant minister of trade and industry Vincent Seretse even applauded the intended derivative market project by reiterating that the derivative contracts will mitigate against price volatility that is endemic to Africa's commodity and financial markets. At the same ceremony of the intended exchange, the regional director of Africa Development bank, Ebrima Faal alluded that in environments where currency and commodity volatility exist causing destabilization of food and energy security, derivatives would be the ideal financial instruments to mitigate the risks and correct the financial markets such as in the African continent. By the end of 2016, Bourse Africa had not yet commenced derivative trading in Botswana and still rather promised to partner with local institutions to offer local university graduates training intrading spot and derivative markets.

PACDEX and Multi Commodity Exchange were the initiatives to begin derivative trading in Botswana as far back as 2006 but up to now no derivative exchange has been implemented in Gaborone Botswana.

\section{The History of Development of Derivative Markets in South Africa}

In 1990, the South African Futures Exchange (SAFEX) started trading in derivatives following the uplifting of agricultural price controls and the deregulation of the South African agricultural market by the government. SAFEX had two divisions: SAFEX Financial Derivatives and SAFEX Agricultural Derivatives. SAFEX was purchased by Johannesburg Stock Exchange (JSE) in 2001 and became a division of the Johannesburg Stock Exchange. The JSE trades in commodity derivatives, agricultural, metals and energy derivatives. Bond Exchange of South Africa was also acquired in 2009 by the Johannesburg Stock Exchange(JSE) and was dealing in debt securities and interest rate futures prior to its acquisition.

\section{Zambia Derivatives Market}

According to an article in the Zambia Daily Mail, the Bond and Derivatives Exchange Zambia Plc became a licensed exchange in 2012. (see https:// www.dailymail.co.zm/bond-derivatives-exchange/) In 2012 BaDex Bond and Derivatives exchange was licenced in Zambia and the derivative market started trading in bonds and derivatives on 16 April 2014 in Lusaka. In recent regional economic developments of the year 2016, the Zambian Commodity Exchange (ZAMACE) signed a partnership agreement with the Johannesburg Stock Exchange (JSE) futures market to boost liquidity in the Zambian 
agricultural commodity market. The Zambia derivative exchange was the third to operate after Mauritius.

\section{Kenyan Derivatives Market}

The Nairobi Securities Exchange existed since 1954 under the name Nairobi Stock Exchange. The derivatives market works under the name "Nairobi Securities Exchange (NSE) Derivatives Market" or NEXT. They currently offer equity index futures and single stock futures. In 2015 the Nairobi Securities Exchange(NSE) was licensed to operate a derivative exchange. In January 2016 six banks comprising of Barclays bank of Kenya, Cooperative Bank of Kenya, CFC Stanbic bank, NIC bank, Chase Bank and CBA bank were signed up by the Nairobi Securities Exchange(NSE) to act as clearing members of the derivative exchange.

\section{Motivation of the Study}

The aftermath of the world food and financial crisis of 2008 experienced a down turn in global growth, a decline and volatility in the commodity prices and a credit crunch which significantly worsened the economic outlook of economies in Sub-Sahara Africa including Zimbabwe, Botswana and South Africa. Risks were rising and it was uncertain how long the crisis would last. The uncertainty and volatility of foreign currency exchange rates and general prices of commodity following the world food and financial crisis has prompted an inquiry into the impediments and evolution of derivatives in Zimbabwean, Botswanan and South African.
The Global competitive index brings together the micro or business aspects and macro economic aspects into a single index which evaluate the ability by countries around the world to provide high levels of prosperity to their citizens. The ability by countries around the world to provide prosperity to their citizens depends on how a productively a country uses resources at its disposal. Hence the $\mathrm{GCl}$ is a measure of a set of institutions, factors and policies that are sustainable for current and medium term levels of economic prosperity. (see https:// en.wikipedia.org/wiki/Global_Competitiveness_ Report). In addition the $\mathrm{GCl}$ the global competitive index captures the determinants of long-term growth. The World Economic Forum, competitiveness report of 2017 to 2018, revealed that Global Competitive Index $(\mathrm{GCl})$ rankings relating to financial market development in Zimbabwe (3.2) and Botswana (4.0) were notably trailing behind that of South Africa (4.4) and the United States of America (5.7). In addition the overall global competitiveness index for the United States of America is 5.85 as compared to South Africa with a 4.32, Botswana has an index of 4.3 and lastly Zimbabwe is trailing behind with an index of 3.32 .

It is also interesting to observe on a comparative note that South Africa's GCI score went from 4.47 to 4.32 from 2016-2017 to 2017-2018. South Africa went from the $47^{\text {th }}$ place to the $61^{\text {st }}$ place and whilst the $\mathrm{GCl}$ score of Zimbabwe worsened. On the other hand, Botswana's GCl improved marginally. Possibly explanation for these changes

Table 1: Key Indicators-Global Competitiveness Index (GCI)

\begin{tabular}{lcccc}
\hline Key Indicators & United States & South Africa & Botswana & Zimbabwe \\
\hline $\begin{array}{l}\text { Global Competitiveness } \\
\text { Index(GCI) }\end{array}$ & 5.85 & 4.32 & 4.3 & 3.32 \\
$\begin{array}{l}\text { Gross Domestic Product } \\
\text { (GDP)-US\$ Billions }\end{array}$ & 18569.10 & 294.10 & 15 & 14.2 \\
GDP Per Capita & 57436.40 & 5260.9 & 6972.10 & 977.4 \\
Population Size-Millions & 321.6 & 55 & 2.1 & 13.4 \\
\hline
\end{tabular}


is attributed to the quality of political governance in each country for instance Zimbabwe's GCI score has been deteriorating and that of South Africa showed signs of declining as well because of deteriorating political and economic governance frameworks in each country. Botswana has a stable and a prudent political framework which is not marked with human rights abuses and hence its $\mathrm{GCl}$ index shows signs of improvingas compared to Zimbabwe and South Africa.

Both United States of America and South Africa have well functional derivative markets linked through Johannesburg Stock Exchange (JSE) of South Africa to the Chicago Mercantile Exchange (CME) of the United States. It was confirmed that higher economic growth are experienced in countries that have established derivative markets than those without. ${ }^{6}$ This anomaly in global competitiveness has propelled a study into the impediments and best practice use of derivatives in Zimbabwe, Botswana and South Africa.

$\mathrm{GCl}$ has twelve pillars but for the purpose and relevance of this study only eight (8) pillars of the $\mathrm{GCl}$ has been considered instead of twelve (12), as those mentioned above in the table strongly influence the initiation and development of derivatives in each country studied.

\section{Problem Statement}

Since the financial crisis of 2008 Zimbabwe and Botswana have not set up a derivative exchanges to address risk in the markets and the study is concerned primarily on exploring the factors that are inhibiting Zimbabwe and Botswana from using derivatives in their markets.

\section{Purpose Of The Research}

The study investigates the best practice use and techniques to be applied to enhance price discovery, stall and reduce significant financial losses by using commodity and financial derivatives to mitigate price risk in the foreign currency and commodity markets of Zimbabwe, Botswana and South Africa. The purpose of the study are as follows;

To explore the factors which inhibit Zimbabwe, Botswana and South Africa from using derivatives.

Table 1.1: Global Competitiveness Index (GCI)

\begin{tabular}{lcccc}
\hline Global Competitive Index & United States & South Africa & Botswana & Zimbabwe \\
\hline Financial Market Development & 5.7 & 4.4 & 4.0 & 3.2 \\
Higher Education Training & 6.1 & 4.1 & 3.8 & 3.1 \\
Macroeconomic Environment & 4.5 & 4.5 & 6.1 & 3.2 \\
Infrastructure & 6.0 & 4.3 & 3.6 & 2.7 \\
Technology Readiness & 6.2 & 4.6 & 3.6 & 2.7 \\
Market Size & 6.9 & 4.9 & 3.0 & 2.8 \\
Business Sophistication & 5.8 & 4.5 & 3.7 & 3.2 \\
Innovation & 5.8 & 3.8 & 3.2 & 2.5 \\
\hline
\end{tabular}

Source: World Economic Forum, Competitiveness report (2017-2018) 
To investigate into the best methods and techniques of applying derivatives in Zimbabwe, Botswana and South Africa.

\section{Research Questions}

What are the factors that prohibit Zimbabwe, Botswana and South Africa from using derivatives?

What is the best practice use of derivatives in Zimbabwe, Botswana and South Africa?

The study sought answers from the Zimbabwe, Botswana and South Africa financial markets.

\section{Contribution of the Study}

The study identified significant gaps in the use of derivatives in Zimbabwe and Botswana. The study contributed towards the encouragement to initiate derivatives exchanges in the financial markets of Botswana and Zimbabwe where gaps in the use of derivative products were identified. The study is instrumental to the development of derivatives policy issues and enactments in the financial markets of Zimbabwe and Botswana. Another contribution of the study is that it has been conceptual in influencing the framing of debates in the financial markets of Botswana and Zimbabwe. Lastly the study contributed to capacity building of the academic communityas graduates and students of Botho University were engaged in the study as research assistants. In addition the study acts as an important insight to policy makers, regulators and financial institutions personnel on the knowledge and benefits of using derivatives in the financial markets of Zimbabwe and Botswana. Another contribution of the study is that it serves to promote and enhance the global competitiveness index of Zimbabwe and Botswana through its encouragement to initiate derivative exchanges in the financial markets. Derivative exchanges are slowly emerging in both countries as the researcher interacted with the non-bankers, regulators, policy makers and bankers of each country during the data collection phase and through the dissemination of the research deliverables of the study.

\section{Prior Literature}

There is little literature review on qualitative surveys that were conducted on the impediments to the evolution of derivatives in Sub-Sahara
Africa and therefore the study also resorted to a literature review of the seminal authors of the world at large.

\section{Derivatives}

A derivative was defined as a financial instrument with a value which depends on the value of the underlying item. ${ }^{7}$ It was asserted that there are several types of financial instruments such as Options, Currency swaps, Interest rate Swaps, Warrants, Forwards, Futures and options. Derivatives are further reinforced as 'financial instruments whose value is derived from the value of an underlying asset (such as gold, wheat or other commodities) or other financial instruments including bonds, or market benchmarks such as interest rates' ${ }^{8}$

\section{Weather Derivatives}

Weather derivatives are financial instruments which are used to provide protection against financial losses caused by adverse weather or weather risk. Weather risk is the volatility to future cash flows caused by non- catastrophic weather. Further it was stated that non-catastrophic weather can be aggregated into events that affect company cash flows but without threatening lives and property. Weather derivatives are mostly applied in energy and agricultural sectors and retail is said to be largest potential use of weather derivatives. ${ }^{9}$ Price Waterhouse Coopers and the Weather Risk management Association (2006) asserted that feasibility of weather derivatives in the retail sector had not been sufficiently studied. It was alluded that depending on the location, hedging with weather derivatives reduced the Value at Risk $(\mathrm{VaR})$ measure to a variable degree, although with a considerable basis risk. ${ }^{10}$

\section{The Factors Affecting the Evolution of Derivatives Markets}

According to the results of a survey comprising of 2000 non-financial companies of varying sizes performed in the United States. It was uncovered through a questionnaire based survey that there was a strong positive correlation between usage of derivatives and firm size with small firms less likely to use derivatives as compared to large firms. In the same study it was discovered that derivatives were used for hedging risk and not for speculative trading. ${ }^{11}$ 
The South African derivative markets stemmed primarily as a necessity to self-insure against volatile capital flows and to manage financial risk associated with the volatility of asset prices. In the same study it was uncovered that the financial markets of South Africa comprised mostly of futures and options. Further it was revealed that tight regulations were evidenced in asset allocation for pension fund and insurance fund to prevent excessive risk taking in the markets. It was recommended by the same study that small sub-Saharan with nascent local securities exchange market would derive particular benefit from listing and trading their derivative instruments on the regional derivative market of South Africa. In addition it was asserted that the advantages of using derivatives should not be discounted and it was proclaimed that the misuse of derivatives could lead to a financial crisis, amplify volatility and accelerate capital outflows. It was affirmed that there was a need to strengthen the regulations pertaining to derivative trading particularly by institutional investors to avoid excess risk taking. In the same study it was noted that hedge funds were barred by the South African Reserve bank until the industry was properly regulated. In the same study it was noted that the enhancement of derivative market development would be brought about by a good system of good corporate governance, transparency, a need for a clear accounting standards, easy tax codes and payment system for derivatives activities. A proclamation was made that over reliance on bank credit as a source of credit could be reduced through the introduction of commodity derivatives and farmers could improve the management of their seasonal risk, albeit with proper regulations and supervision. The study was prepared as a working paper for International Monetary Fund to elicit views, comments and further debate. ${ }^{12}$

A study was performed through a qualitative research study with fund managers, financial analysts and dealers of asset management firms in Harare, Zimbabwe using questionnaires and interviews. The study uncovered the following factors as hindrances to the establishment of derivatives in Zimbabwe; irregularities in the regulatory framework as insider dealing was prevalent in the trading of shares on the local bourse and inadequate institutional arrangements that comprised the regulatory framework of Zimbabwe. The study revealed that the market participants believed that the Zimbabwe Stock Exchange (ZSE) has the capacity and that it can handle derivative trading. In the same study it was affirmed that derivatives would enable tactical investment decision making through the creation of new avenues of risk management enabled by speculation, arbitrage and leverage techniques. It was discovered in the study that fund managers preferred hedging with options as a result of the buoyant nature of the Zimbabwe Stock Exchange Index. The same study revealed that call options were more popular than put options because of the volatile nature of the Zimbabwe economy. ${ }^{13}$

In the study on "liquidity derivatives a solution to Zimbabwe economic liquidity problems" which was conducted on the Zimbabwe Stock Exchange listed OK retail daily share movement with an aim to determine whether Zimbabwe Stock Exchange was the source of the liquidity crisis in Zimbabwe or not, it was study discovered that the Zimbabwe Stock Exchange performance as a source of the liquidity crisis and financial innovations were required in Zimbabwe to curb the liquidity crisis. The study was conducted based on an analysis of the price velocity and price acceleration of the Zimbabwe Stock Exchange (ZSE) listed OK retail daily share price movements taken from February 2009 to October 2012. In the study it was uncovered that the performance of the Zimbabwe Stock Exchange was a source of the liquidity crisis and that liquidity derivatives were required to hedge risk and to resolve the liquidity crisis in Zimbabwe. ${ }^{14}$

In another study conducted in Zimbabwe derivatives sector was identified as a missing link to economic development and to a viable financial sector in Zimbabwe financial sector. The study was based on an analysis of the economic importance of using derivatives in developing nations with particular reference to the Zimbabwe financial sector. The study was aimed to be a policy prescription to encourage policy makers to create a conducive environment and legal framework to facilitate derivative trading in the Zimbabwe financial sector.There was no specific methodology that was mentioned and applied in the study. ${ }^{15}$

The study conducted in South Africa on the institutionalization of derivative trading and 
economic growth based on a dummy-based Generalised Method of Moment (GMM) regression conducted first on the data over the period 1971-2012, the post-1990 establishment of the derivatives exchange was especially emphasized on investigating the relationship between growth of GDP and South Africa futures Exchange (SAFEX)'s historical derivatives trading volumes in terms of the causality study. ${ }^{16}$ It was further uncovered that sound regulatory framework remained a vital requirement for a successful derivative market and that regulations should be evolving that support the innovation of the markets and that provide up to date regulatory environment for the market at all times. ${ }^{17}$ In the same paper it was affirmed that the development of derivative trading should follow that of bond and equity exchanges that would create the need for derivatives. ${ }^{18}$

It was further alluded that derivative exchanges in Sub-Saharan Africa are most likely to add value to economic growth if competitive derivative instruments are offered on commodities such as oil, gold, coffee etc. since they are already offered to buyers and seller to hedge risk by other international derivative exchanges. In addition it was revealed that economic growth leads to the development of derivative markets and that the expansion of the economy is the factor that creates new demands for derivative instruments in a particular country. Positively it was uncovered that derivative exchanges are credited with a decreasing effect on economy volatility and that derivatives lead to more stable economic conditions under the unique circumstances of a developing country (the findings supports Tiberiu's 2007 report)..$^{19}$

In a similar study conducted in Bangladesh through a qualitative research approach involving content analysis of books, journals and other publications, it was revealed that there was a necessity for Bangladesh to develop a derivative market as it will foster capital market development, reduce volatility in the capital markets and enhance globalization of the financial markets. In the same study it was revealed that the best practice ways of establishing a derivative markets in Bangladesh were, to have a liquidity financial market, an advisory committee for conducting a feasibility study, to restructure Bangladesh Securities Exchange Commission, to have stakeholder awareness, to deepen the capital markets, proper coordination, sophistication of infrastructure and international integration were also required. ${ }^{20}$

In a study performed through a descriptive survey of 44 commercial banks in Kenya, it was exposed that the Kenyan financial markets were predominantly using over the counter derivatives such as forward contracts, swaps and options. The study was conducted through a descriptive survey involving distribution of questionnaires to 44 commercial banks using derivatives. In the study it was revealed that the swaps, forward contracts and options were used to hedge against risk of volatility of interest rates and the depreciation of Kenyan currency. It was observed in the study that the factors that inhibited the development of derivatives in Kenya were; poor structural facilities, inaccessibility to trading platforms, poor trading systems, weak trading rules and the non-existence of central counterparty. ${ }^{21}$

According to another study it was noted that emerging markets were recommended to follow the supply-leading pattern of development by developing derivative products based on the most liquid spot market financial products which were supported by appropriate institutional and legal arrangements. Supply-leading pattern were regarded as an active approach of promoting economic development by establishing the financial infrastructures in an economy. In the same study involving a panel data results for emerging markets, it was revealed that derivative market development is dependent on the financial system development level of these countries. The study was based on a selection of 11 countries comprising of 5 from developed and 6 drawn from emerging markets and the derivative exchanges were chosen based on the availability of data and geographical diversification. The hypothesis for the study was based on Levine's (1997) functional approach that a positive relationship exist between derivative market developments with economic growth caused by increased capital formation over a period of time. The study was based on a single regression equation including the use of both liquidity and capitalization impact model and the Granger's 
causality test (1969) was utilized in the study to check the direction of both economic growth and financial development indicators with the derivative market liquidity level. ${ }^{22}$

The results of the liquidity impact model revealed that there was a negative correlation between derivative market development and economic growth particularly in all the developed countries that were studied. Under the capitalization impact model a positive coefficient was found in 5 out of 6 of the emerging countries that were studied supporting the hypothesis that a positive relationship exist between derivative market development with economic development. In conclusion it was affirmed that emerging countries with well developed derivative markets experienced a higher economic growth than countries without. ${ }^{23}$

In a similar study it was noted that the existence of derivative markets in an economy contributed significantly to positive country growth and that the development of derivative exchanges in a country decreases GDP growth volatility. ${ }^{24}$ In addition it was pointed out that derivative markets were a factor of development in capital markets and a contributor towards financial markets completeness. It was further stressed that derivative markets encouraged the establishment of competitive and sophisticated business environments leading to significant growth in developing countries. In addition it was asserted that the evolution of derivatives was possible only if accompanied by adequate infrastructure to support such innovative financial products. ${ }^{25}$

Derivatives were viewed as time bombs both for the parties that deal in them and the economic system. Further derivatives were described as instruments that call for money to change hands at some future date and the amount being determined by one or more reference items such as interest rates, stock prices and currency values. Another problem associated with derivatives was that they have a pile-on effect, meaning that they exacerbate trouble that a corporation has run into, for a completely unrelated reasons because many derivatives require that any institution that has suffered a downgrade for whatever reasons must supply collateral to counterparties. Finally another problem of derivatives was that derivatives created a daisy chain risk that is akin to the risk run by insurers or reinsurers that lay off much of their business with others. ${ }^{26}$

\section{Methodology}

The study used the qualitative research methods, predominantly involving a questionnaire survey method in the gathering of responses from the participants on the impediments of using derivatives in the markets of Zimbabwe, Botswana and South Africa. A total of one hundred questionnaires were distributed in each of the money and capital markets of Zimbabwe, Botswana and South Africa. The population of the study for each country comprised of asset managers, brokers, financial risk managers, treasury managers, back office managers and policy makers for financial markets. Qualitative research is the research where studies are set in their natural settings and humans are the essential instrument. Further qualitative research can be described as the research where the understanding and meaning is based on verbal narratives and observations rather than numbers. ${ }^{27}$

The qualitative research methodology based on a questionnaire survey was appropriate for the study since it is a similar method for similar studies that were conducted by Phillips (1995) and Bodnar, Hayt, Marstonand Smithson (1995) in the United States on theusage of derivatives by non-financial firms and similar studies in the world had followed the precedent.

\section{Data Analysis}

The following charts were generated from the responses received from the questionnaires that were administered in each of the financial markets of Zimbabwe, Botswana and South Africa.

\section{Interpretation of the Findings in South Africa}

Options (80\%) and Futures (80\%) were uncovered as very effective at addressing commodity price risk in the commodity markets of South Africa (view chart 1).

In South Africa the study revealed that political factors $(50 \%)$, economic factors $(42 \%)$ and legal 
Effectiveness of commodity derivatives in addressing risk in South Africa.

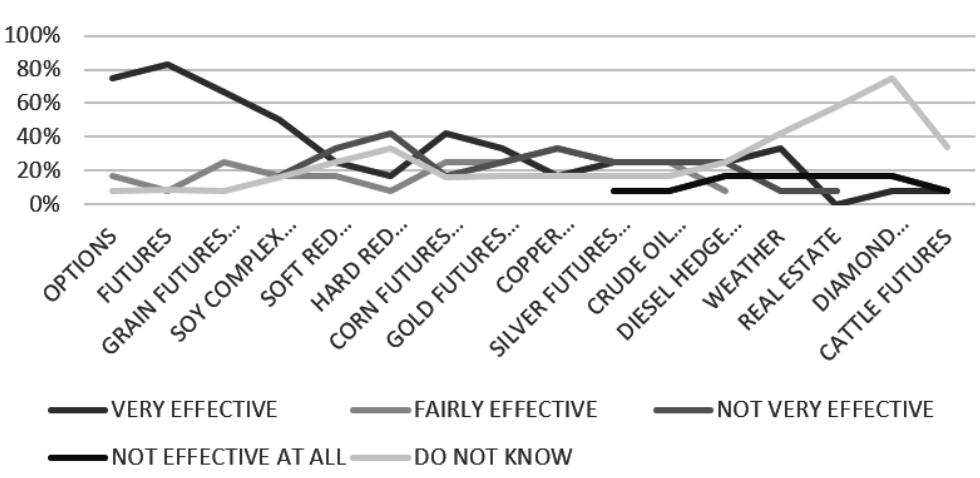

Chart 1: The Results of the Effectiveness of Commodity Derivatives in Addressing Risk in the Commodity Markets of South Africa

Results of the impediments of using derivatives in South Africa.

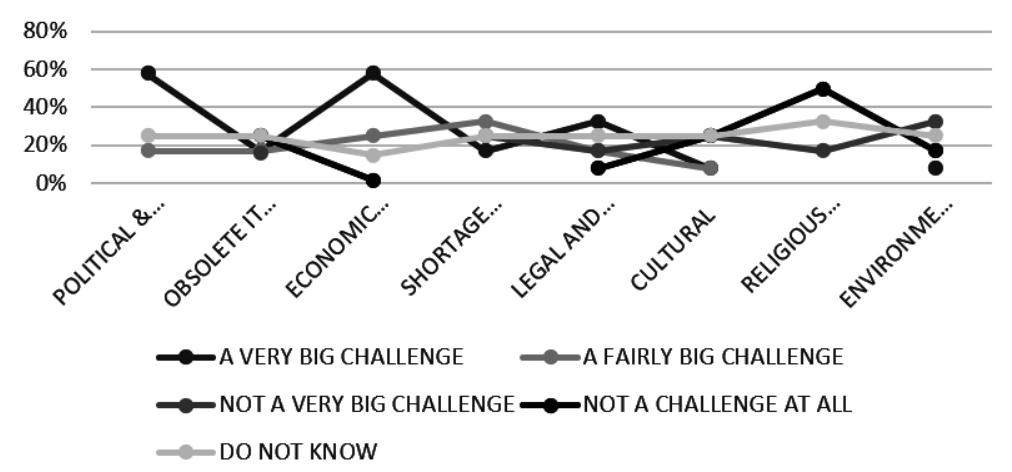

Chart 2: The Results of the Impediments of Using Derivatives in South Africa

The results of the impact on payoffs for using derivatives in South Africa.

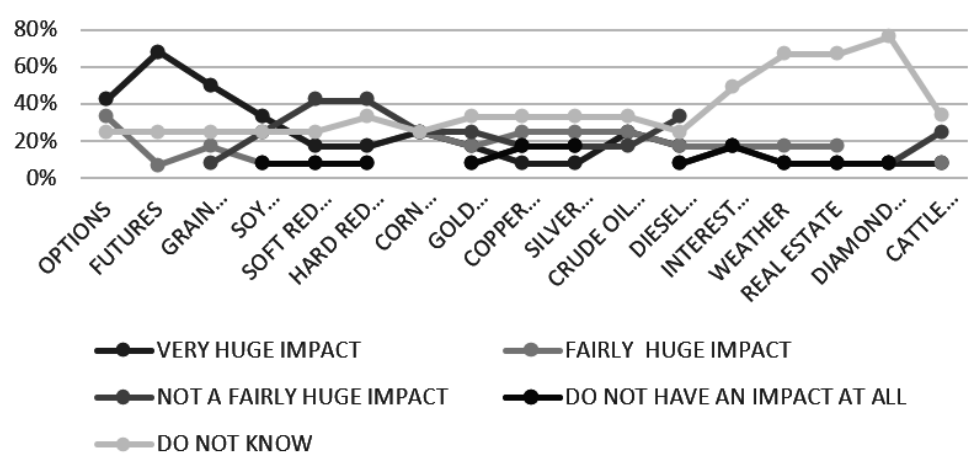

Chart 3: The Results of the Impact on Payoffs for Using Derivatives in South Africa 
The results of the best practice use of derivatives

in South Africa.

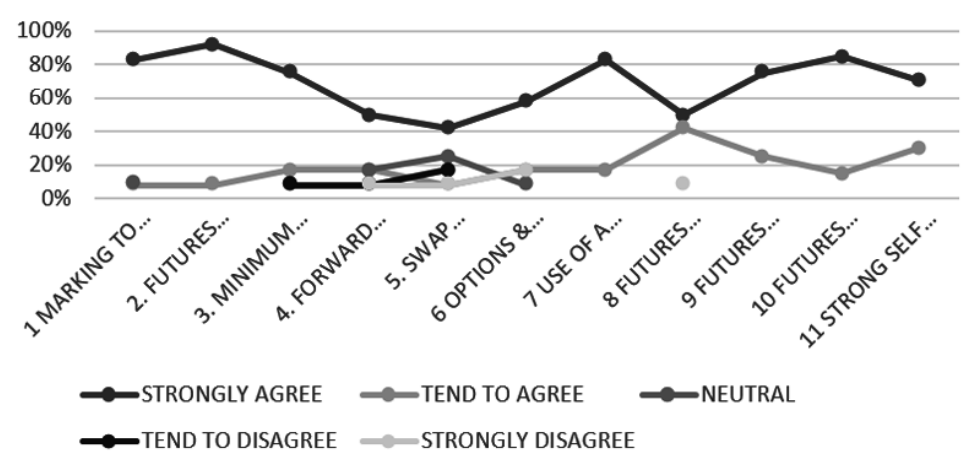

Chart 4: Results of the Best Practice Use of Derivatives in South Africa

The results of the effectiveness of commodities derivatives in Botswana.

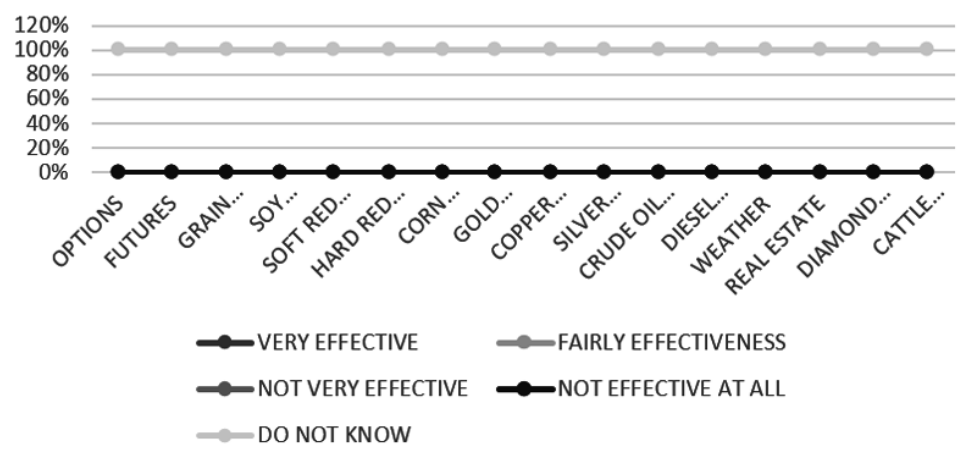

Chart 5: The Results of The Effectiveness of Commodity Derivatives at Addressing Risk in The Commodity Markets of Botswana

The results of the impediments of using commodities derivatives in Botswana.

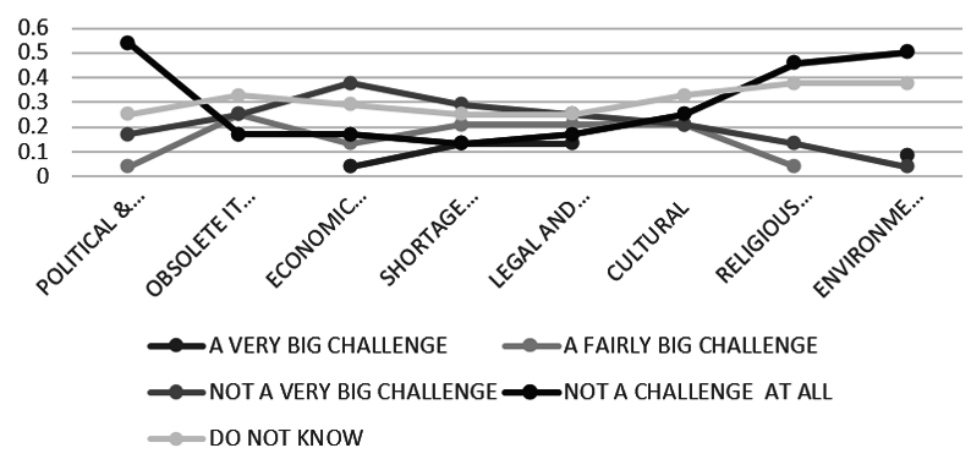

Chart 6: The Results of The Impediments of Using Derivatives in Botswana 
factors $(32 \%)$ were a very big challenge and impediments of using derivative products in South Africa (view chart 2).

The study reflected that options and futures (60\%) have a very huge impact on payoffs in addressing risk in the financial markets of South Africa (view chart 3).

The best practice use of derivatives were noted as; marking to market $(80 \%)$ the futures, requiring margin calls for futures $(85 \%)$, strong self-regulation

$(70 \%)$ of derivative markets, central clearance $(82 \%)$ and having limit orders $(75 \%)$ on futures deals (see chart 4 above).

\section{Botswana}

The following charts are the results of responses that were obtained in Botswana.

\section{Interpretation of the Findings in Botswana}

The study revealed that at the time the study was conducted they were no commodity derivatives in Botswana (see chart 5).

The study conducted in Botswana uncovered those obsolete information systems $(20 \%)$, shortages of staff $(18 \%)$ and cultural factors $(20 \%)$ were a fairly big challenge of using derivatives in Botswana (see chart 6).

\section{Zimbabwe}

The charts belowsummarizes the responses received from the questionnaires that were administered in the money and capital markets of Zimbabwe.

\section{Interpretation Of The Findings In Zimbabwe}

The study revealed that there were no commodity derivatives in Zimbabwe at the time when the study was conducted (see chart 7).

The respondents in Zimbabwe revealed that political factors $(48 \%)$ and economic factors $(65 \%)$ were a very big challenge and impediments of evolution of derivatives in Zimbabwe (see chart 8).

\section{Conclusion}

Factors That Prohibit Zimbabwe From Setting Up A Commodity Derivative Exchange

In Zimbabwe the economic sanctions, laws and regulations should beamended and adapted to overcome the market uncertainties and accommodate the use of futures, options, swaps and other derivatives. The fundamental impediment that has blocked economic progress are the hard economic sanctions targeted on the country through the Zimbabwe Democracy and Economic Recovery (ZiDERA) Act of 2001.

In Zimbabwe recently a bill was put into parliament on $22^{\text {nd }}$ March 2018 as an attempt to amend the ZiDERA Act of 2001. The bill is the first stage of the legislative process to circumvent sanctions that were imposed on Zimbabwe.

The absence of a prudent bond market in Zimbabwe has resulted in a lack of an appropriate benchmark for the pricing of derivatives as the development of derivative markets follow that of the equity and bond markets. The framework for pricing derivatives would be complex without an established bond and equity indexed markets.

The Best Practice Use of Derivatives in Zimbabwe The Zimbabwe farmers' community can also benefit from the use of weather derivatives to counter against the risk of financial losses arising from the average changes in the average weather. The use of weather derivatives could be suitably applied in energy, tourism, crop and dairy farming production. Further the real estate derivatives could be vital in the property sector to hedge against losses resulting from significant fluctuations in the property prices.

\section{Factors That Prohibit Botswana From Setting Up a Commodity Derivative Exchange}

In Botswana the Non-Banking Financial Regulatory Authority(NBFIRA) published the revised 2017 version of the fund investment rules (PFR2) with regard to pension prudential rules in terms of section 4(d) of the NBFIRA Act of 2016 which is read with 
section 52 of the Retirement Funds act of 2014, with regard to the use of pension funds, it was provided that, a fund shall not use derivatives other than for the purpose of efficient portfolio management and for the purpose of reducing investment risk, upon obtaining approval in writing from an actuary. Derivatives are regarded to be at the infancy stages of development at the Botswana Stock Exchange (BSE).Arobust derivative exchanges cannot be established in a short time period. ${ }^{28}$

The Best practice Use of Derivatives in Botswana It is clearly evidenced that in Botswana the application of derivatives is provided for in the laws and regulation of Botswana. The Non-Banking
Financial Institutions Regulatory (NBFIRA) of Botswana should support the use of derivatives through setting up a "futures project steering committee" that would assess further the economic, legal, financial and technical feasibility of the project.

\section{Suggested Course of Action For Botswana and Zimbabwe}

Setting up a derivative exchange in Botswana and Zimbabwe would require it to be integrated with regional derivatives exchange such as Johannesburg Stock Exchange (JSE) as well as global derivative exchanges to benefit from economies of scale and to enhance significant capital flows from outside the countries.

\section{The results of the effectivess of using commodities derivatives in addressing risks in Zimbabwe}

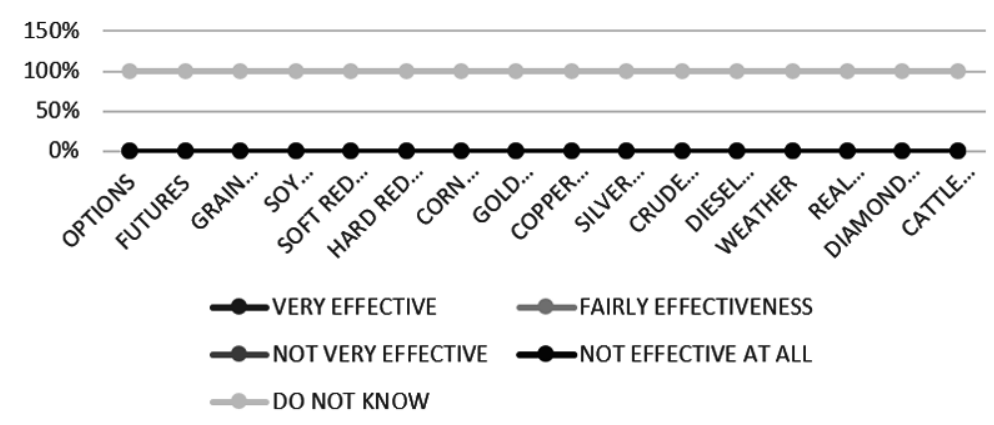

Chart 7: The Results of The Effectiveness of Commodity Derivatives at Addressing Risk in The Commodity Markets Of Zimbabwe

\section{Results of the impediments of using commodities derivatives in Zimbabwe.}

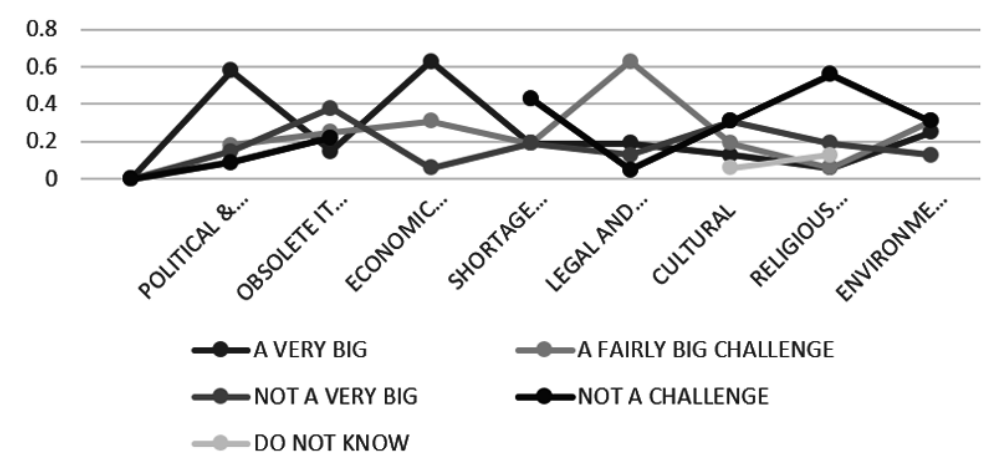

Chart 8. The Results of The Impediments of Using Derivatives in Zimbabwe 
The supervision of the proposed derivative exchange should be predominantly instituted through a self-regulation approach, although government monitoring would also be required up to a reasonable extent for the protection of public interest. The initiation of a futures andoption exchange in both countries could be a fundamental solution to most of the problems that the countries are facing regarding the uncertainty of prices of Diamonds, Cattle, Gold and other metals.

All Futures and options deals should be standardized, marked to market and be centrally cleared. The use of futures contracts withlimit order and stop loss order is highly recommendable in the event that both Zimbabwe and Botswana established a derivative market in the future.

\section{South Africa}

In South Africa linear products such as forwards, futures and currency swaps are effective for hedgers as they align and match the linear exposure of forex deals. Options are also attractive to hedgers and inaddition they protect against the downside and hence are expensive as they demand payment of a premium upfront.

In the South African financial markets investors can use interest rate collars, floors, capsand options to hedge against financial losses resulting from the changes in interest rates, as the interest rates are correlated in a fundamental manner to foreign exchange rates.

In South Africa limit orders, stop-loss orders, marking to market of future deals, using futures with margin payments requirements are the preferable mode of applying futures in the markets to enable protection against counterparties' risk. In addition over the counter derivatives such as swaps and forwards should be applied as standardized contracts that should be cleared through central repositories to reduce systemic risk on the deals. Furtheraccounting transparency and effective communication preferably on a real time basis of derivative deals' information, should inevitablybe a requirement of the effective operation of the exchanges in South Africa.

\section{Implications for the Future Research}

The study focused only on three (3) out of the forty nine (49) countries in sub-Sahara Africa and as such future research on the evolution and initiation of derivatives should be focused on countries on the northern part of sub-Sahara Africa. The focus for the study could be based on those countries of sub-Saharan which are densely populated for instance like Nigeria (175 million), Ghana (24 million), Cameroon (19 million), Democratic republic of Congo (69 million), Kenya (39 million), Ethiopia (89 million), Tanzania (45 million), Sudan (32 million), Angola (18 million), Ivory Coast (21 million) and Uganda (32 million). Initiation of derivatives in such countries could be of immense value to raising of standard of living and fueling of economic growth in Africa, as size of the population matters, in the initiation and evolution of commodity exchanges.

\section{Acknowledgment}

I would like to thank Prof. Kuzvinetsa Dzvimboand Dr. Morgen Chawawa for their significant contribution to the research. In addition I would make special mention to the following BSc Accounting Honors graduates, student class of 2018, of Botho University, who took part in the research as research assistants; Neelo Sealaphiri, Tankiso Motlogelwa, Ikakanyetseng Dorothy Tekanyo, Oteng Ntshole, Gelebaone Keetseope, BongoitloTamuku, Raditholo Bogosi, Thonisani, Tshegofatso Letebele, Michael, Tlhomo, Kgomotso Thanki, Ediaslsake, Adelaide Mokotswe, Ditiro Chinga, Bophelo Moatlhodi, Othusitse R. Sarefo, Thuso Oabile, Pono Mokokong, Boitswarelo Motlogelwa, Kefilwe Sekgetle, Thato Gare and Boitumelo Gouwe.

\section{References}

1. Hull, J.C. (2017). Options, Futures and Other Derivatives, 6th Edition. Prentice-Hall, London, 2006.

2. Hull, J.C. (2017). Options, Futures and
Other Derivatives, 6th Edition. Prentice-Hall, London, 2006.

3. IOSCO (1994), report of the development committee task force on derivatives, 
September 1994

4. Warren Buffet on Derivatives (2002). Edited excerpts from the Berkshire Hathaway annual report for 2002. (see http://berkshirehathaway. com/2002ar/2002ar.pdf).

5. Arusha Declaration and plan of action on African Commodities-African Union Conference of Ministers of Trade and Commodities 21-23 November 2005, Arish, United Republic of Tanzania.

6. endeniz-yüncü (2007). Futures market development and economic growth.

7. Elton, E.J., \& Gruber M.J. (1995) Modern Portfolio Theory and Investment Analysis, 5th Edition, Wiley, New York

8. Source: Jeremy Grant, Editor of The Trading Room, Richard Milne, European Business Correspondent and Aline van Duyn, US Markets Editor, Financial Times. (see http:// lexicon.ft.com/Term?term=derivatives).

9. Torriani, D.S., Calanca, P., Beniston, M. and Fuhrer, J. (2008). 'Hedging with weather derivatives to cope with climate variability and change Grain Maize Production', Agricultural Finance Review 68(1):67-81.

10. Torriani, D.S., Calanca, P., Beniston, M. \& Fuhrer, J. (2008). 'Hedging with weather derivatives to cope with climate variability and change Grain Maize Production', Agricultural Finance Review 68(1):67-81.

11. Bodnar, G. M., Hayt, G.M., Marston, R.C. \& Smithson,C.W. (1995). "Wharton Survey of derivative usage of derivatives by US non -financial firms". Financial Management 24 (Summer), 104-114.

12. Olatundun J. A. (2009). The derivative markets in South Africa-Lessons for Sub-saharan Africa International Monetary Fund Working Paper No. 09/196.

13. Kosmas, N. (2010). Derivative Market: An integral part of the Zimbabwe Stock Exchange. Annals of the University of Petrosani, Economics, 10(1), 217-228.

14. Wilbert, C. (2013). Liquidity derivatives as solution to Zimbabwean economic liquidity problems. Global Advanced Research Journal of Economics, Accounting and Finance, 2(3), 67-72.

15. Wellington, G. B. \& Cloudio, K. C. \& Rodrick, S. (2015). The need for financial Stability in Zimbabwe: use of derivative securities. IOSR Journal of Economics and Finance,
6(4), 6-14.

16. Andrey, N. B. (2015). Institutionalisation of Derivatives Trading and Economic Growth: Evidence from South Africa.

17. Tsetsekos, G. \& Varangis, P. (1997). The structure of derivatives exchanges: Lessons from developed and emerging markets. Alberta Market Solutions. (2003). Derivatives market development: Key success factors in building a new derivatives market $A$ White Paper from Alberta Market Solutions Ltd.

18. Andrey, N. B. (2015). Institutionalisation of Derivatives Trading and Economic Growth: Evidence from South Africa.

19. Andrey, N. B. (2015). Institutionalisation of Derivatives Trading and Economic Growth: Evidence from South Africa.

20. Md, H. R. \& Bijoy, C. D. (2015).Necessity of the Establishment of a Financial Derivative Market in Bangladesh. International Journal of Management Science and Business Administration, 2(1), 20-31.

21. Michael, R. E. (2016) Factors that inhibit the development of financial derivatives in the Kenyan financial sector

22. Baluch, A. \& Ariff. M. (2007). Derivatives markets and economic growth: Is there a relationship? Australia: Bond University Globalisation \& Development Centre.

23. Baluch, A. \& Ariff. M. (2007). Derivatives markets and economic growth: Is there a relationship? Australia: Bond University Globalisation \& Development Centre.

24. Rodrigues, P., Schwarz, C. \& Seeger, N. (2012). Does the institutionalization of derivatives trading spur economic growth?

25. Ngugi, R., Amanja, D. \& Maana, I. (2009). Capital market, financial deepending and economic growth in Kenya. Available from: http://www.csae.ox.ac.uk/conferences/2009EDiA/papers/513-Isaya.pdf.

26. Warren Buffet on Derivatives (2002). Edited excerpts from the Berkshire Hathaway annual report for 2002. (see http://berkshirehathaway. com/2002ar/2002ar.pdf)

27. Lincoln, Y. S., \& Guba, E. G. (1985). Naturalistic Inquiry. Newbury Park, CA: Sage Publications

28. Standley, S. (2010). What are the determinants of financial market development in subSaharan Africa? Africa's Financial Markets: A Real Development Tool? 5, pp. 17-19. 